

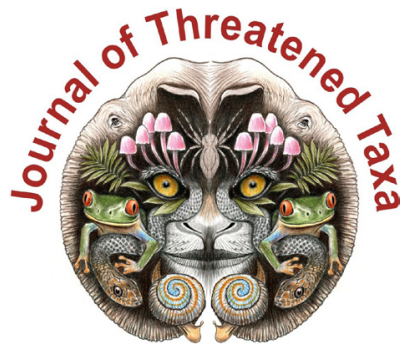

ISSN 0974-7907 (Online); ISSN $0974-7893$ (Print)

Publisher

Host

Wildlife Information Liaison Development Society

www.wild.zooreach.org

Zoo Outreach Organization www.zooreach.org

No. 12, Thiruvannamalai Nagar, Saravanampatti - Kalapatti Road, Saravanampatti, Coimbatore, Tamil Nadu 641035, India

Ph: +91 9385339863 | www.threatenedtaxa.org

Email: sanjay@threatenedtaxa.org

EDITORS

\section{Founder \& Chief Editor}

Dr. Sanjay Molur

Wildlife Information Liaison Development (WILD) Society \& Zoo Outreach Organization (ZOO),

12 Thiruvannamalai Nagar, Saravanampatti, Coimbatore, Tamil Nadu 641035, India

\section{Deputy Chief Editor}

Dr. Neelesh Dahanukar

Noida, Uttar Pradesh, India

\section{Managing Editor}

Mr. B. Ravichandran, WILD/ZOO, Coimbatore, India

\section{Associate Editors}

Dr. Mandar Paingankar, Government Science College Gadchiroli, Maharashtra 442605, India

Dr. Ulrike Streicher, Wildlife Veterinarian, Eugene, Oregon, USA

Ms. Priyanka Iyer, ZOO/WILD, Coimbatore, Tamil Nadu 641035, India

Dr. B.A. Daniel, ZOO/WILD, Coimbatore, Tamil Nadu 641035, India

\section{Editorial Board}

Dr. Russel Mittermeier

Executive Vice Chair, Conservation International, Arlington, Virginia 22202, USA

\section{Prof. Mewa Singh Ph.D., FASc, FNA, FNASc, FNAPsy}

Ramanna Fellow and Life-Long Distinguished Professor, Biopsychology Laboratory, and Institute of Excellence, University of Mysore, Mysuru, Karnataka 570006, India; Honorary Professor, Jawaharlal Nehru Centre for Advanced Scientific Research, Bangalore; and Adjunct Professor, National Institute of Advanced Studies, Bangalore

\section{Stephen D. Nash}

Scientific Illustrator, Conservation International, Dept. of Anatomical Sciences, Health Sciences Center, T-8, Room 045, Stony Brook University, Stony Brook, NY 11794-8081, USA

\section{Dr. Fred Pluthero}

Toronto, Canada

\section{Dr. Priya Davidar}

Sigur Nature Trust, Chadapatti, Mavinhalla PO, Nilgiris, Tamil Nadu 643223, India

\section{Dr. Martin Fisher}

Senior Associate Professor, Battcock Centre for Experimental Astrophysics, Cavendish

Laboratory, JJ Thomson Avenue, Cambridge CB3 OHE, UK

\section{Dr. John Fellowes}

Honorary Assistant Professor, The Kadoorie Institute, 8/F, T.T. Tsui Building, The University of Hong Kong, Pokfulam Road, Hong Kong

\section{Prof. Dr. Mirco Solé}

Universidade Estadual de Santa Cruz, Departamento de Ciências Biológicas, Vice-coordenado do Programa de Pós-Graduação em Zoologia, Rodovia Ilhéus/Itabuna, Km 16 (45662-000)

Salobrinho, Ilhéus - Bahia - Brasil

\section{Dr. Rajeev Raghavan}

Professor of Taxonomy, Kerala University of Fisheries \& Ocean Studies, Kochi, Kerala, India

\section{English Editors}

Mrs. Mira Bhojwani, Pune, India

Dr. Fred Pluthero, Toronto, Canad

Mr. P. Ilangovan, Chennai, India

Web Development

Mrs. Latha G. Ravikumar, ZOO/WILD, Coimbatore, India

\section{Typesetting}

Mr. Arul Jagadish, ZOO, Coimbatore, India

Mrs. Radhika, ZOO, Coimbatore, India

Mrs. Geetha, ZOO, Coimbatore India
Fundraising/Communications

Mrs. Payal B. Molur, Coimbatore, India

Subject Editors 2018-2020

Fungi

Dr. B. Shivaraju, Bengaluru, Karnataka, India

Dr. R.K. Verma, Tropical Forest Research Institute, Jabalpur, India

Dr. Vatsavaya S. Raju, Kakatiay University, Warangal, Andhra Pradesh, India

Dr. M. Krishnappa, Jnana Sahyadri, Kuvempu University, Shimoga, Karnataka, India

Dr. K.R. Sridhar, Mangalore University, Mangalagangotri, Mangalore, Karnataka, India

Dr. Gunjan Biswas, Vidyasagar University, Midnapore, West Bengal, India

\section{Plants}

Dr. G.P. Sinha, Botanical Survey of India, Allahabad, India

Dr. N.P. Balakrishnan, Ret. Joint Director, BSI, Coimbatore, India

Dr. Shonil Bhagwat, Open University and University of Oxford, UK

Prof. D.J. Bhat, Retd. Professor, Goa University, Goa, India

Dr. Ferdinando Boero, Università del Salento, Lecce, Italy

Dr. Dale R. Calder, Royal Ontaro Museum, Toronto, Ontario, Canada

Dr. Cleofas Cervancia, Univ. of Philippines Los Baños College Laguna, Philippines

Dr. F.B. Vincent Florens, University of Mauritius, Mauritius

Dr. Merlin Franco, Curtin University, Malaysia

Dr. V. Irudayaraj, St. Xavier's College, Palayamkottai, Tamil Nadu, India

Dr. B.S. Kholia, Botanical Survey of India, Gangtok, Sikkim, India

Dr. Pankaj Kumar, Kadoorie Farm and Botanic Garden Corporation, Hong Kong S.A.R., China

Dr. V. Sampath Kumar, Botanical Survey of India, Howrah, West Bengal, India

Dr. A.J. Solomon Raju, Andhra University, Visakhapatnam, India

Dr. Vijayasankar Raman, University of Mississippi, USA

Dr. B. Ravi Prasad Rao, Sri Krishnadevaraya University, Anantpur, India

Dr. K. Ravikumar, FRLHT, Bengaluru, Karnataka, India

Dr. Aparna Watve, Pune, Maharashtra, India

Dr. Qiang Liu, Xishuangbanna Tropical Botanical Garden, Yunnan, China

Dr. Noor Azhar Mohamed Shazili, Universiti Malaysia Terengganu, Kuala Terengganu, Malaysia

Dr. M.K. Vasudeva Rao, Shiv Ranjani Housing Society, Pune, Maharashtra, India

Prof. A.J. Solomon Raju, Andhra University, Visakhapatnam, India

Dr. Mandar Datar, Agharkar Research Institute, Pune, Maharashtra, India

Dr. M.K. Janarthanam, Goa University, Goa, India

Dr. K. Karthigeyan, Botanical Survey of India, India

Dr. Errol Vela, University of Montpellier, Montpellier, France

Dr. P. Lakshminarasimhan, Botanical Survey of India, Howrah, India

Dr. Larry R. Noblick, Montgomery Botanical Center, Miami, USA

Dr. K. Haridasan, Pallavur, Palakkad District, Kerala, India

Dr. Analinda Manila-Fajard, University of the Philippines Los Banos, Laguna, Philippines

Dr. P.A. Sinu, Central University of Kerala, Kasaragod, Kerala, India

Dr. Afroz Alam, Banasthali Vidyapith (accredited A grade by NAAC), Rajasthan, India

Dr. K.P. Rajesh, Zamorin's Guruvayurappan College, GA College PO, Kozhikode, Kerala, India

Dr. David E. Boufford, Harvard University Herbaria, Cambridge, MA 02138-2020, USA

Dr. Ritesh Kumar Choudhary, Agharkar Research Institute, Pune, Maharashtra, India

Dr. Navendu Page, Wildlife Institute of India, Chandrabani, Dehradun, Uttarakhand, India

\section{Invertebrates}

Dr. R.K. Avasthi, Rohtak University, Haryana, India

Dr. D.B. Bastawade, Maharashtra, India

Dr. Partha Pratim Bhattacharjee, Tripura University, Suryamaninagar, India

Dr. Kailash Chandra, Zoological Survey of India, Jabalpur, Madhya Pradesh, India

Dr. Ansie Dippenaar-Schoeman, University of Pretoria, Queenswood, South Africa

Dr. Rory Dow, National Museum of natural History Naturalis, The Netherlands

Dr. Brian Fisher, California Academy of Sciences, USA

Dr. Richard Gallon, llandudno, North Wales, LL30 1UP

Dr. Hemant V. Ghate, Modern College, Pune, India

Dr. M. Monwar Hossain, Jahangirnagar University, Dhaka, Bangladesh

Mr. Jatishwor Singh Irungbam, Biology Centre CAS, Branišovská, Czech Republic.

Dr. Ian J. Kitching, Natural History Museum, Cromwell Road, UK

Dr. George Mathew, Kerala Forest Research Institute, Peechi, India

For Focus, Scope, Aims, and Policies, visit https://threatenedtaxa.org/index.php/JoTT/aims_scope
For Article Submission Guidelines, visit https://threatenedtaxa.org/index.php/JoTT/about/submissions
For Policies against Scientific Misconduct, visit https://threatenedtaxa.org/index.php/JoTT/policies_various

continued on the back inside cover 


\title{
First record of a freshwater crab, Maydelliathelphusa masoniana (Henderson, 1893) (Decapoda: Brachyura: Gecarcinucidae) from West Bengal, India
}

\author{
Ram Krishna Das (D) \\ Department of Industrial Fish \& Fisheries, Asutosh College, 92, S.P. Mukherjee Road, Kolkata, West Bengal 700026, India. \\ ramkrishnazoology@gmail.com
}

\begin{abstract}
The genus Maydelliathelphusa Bott, 1969 includes five species, M. masoniana (Henderson, 1893), M. edentula (Alcock, 1909), M. falcidigitis (Alcock, 1910), M. harpax (Alcock, 1909), and M. lugubris (Wood-Mason, 1871), and is endemic to India. Out of the five species, only Maydelliathelphusa lugubris (Wood-Mason, 1871) was reported from West Bengal previously. Present study reports the second species, M. masoniana (Henderson, 1893), from West Bengal, India for the first time.
\end{abstract}

Keywords: Crustacea, Decapoda, description, diagnosis, endemic, freshwater crabs, Gecarcinucidae, taxonomy.

Freshwater crabs belonging to infraorder Brachyura of order Decapoda are important in terms of nutrient cycles, bio-indicators of environments, disease transmission and small scale fisheries (Cumberlidge et al. 2009; Valarmathi 2017; Harhoglu et al. 2018; Kotwal \& Sharma 2020). They are characterized by a broad carapace-covered cephalothorax having five pairs of thoracic legs or pereiopods (one pair of chelipeds, four pairs of walking legs) and a reduced abdomen (Deb 1999; Yeo et al. 2008). These crabs complete their entire life cycle in freshwater environments without moving to saltwater (Yeo et al. 2008).

The freshwater crab diversity of India comprises a total of 127 species divided into two families: Potamidae Ortmann, 1896 and Gecarcinucidae Rathbun, 1904 (Pati
2021). The genus Maydelliathelphusa Bott, 1969 belongs to the Gecarcinucidae and is represented by five species: M. masoniana (Henderson, 1893), M. edentula (Alcock, 1909), M. falcidigitis (Alcock, 1910), M. harpax (Alcock, 1909), and M. lugubris (Wood-Mason, 1871) (Ng et al. 2008). All of these are found in India (Valarmathi 2017), but only M. lugubris is reported from West Bengal (Deb 1999). The present study records $M$. masoniana for the first time from West Bengal.

\section{MATERIALS \& METHODS}

During an ichthyological survey, two specimens of $M$. masoniana were collected from a small stream $\left(26.229^{\circ} \mathrm{N}\right.$, $89.255^{\circ} \mathrm{E}$, elevation $32 \mathrm{~m}$ ) of the Brahmaputra River system in Cooch Behar district, West Bengal, India (Image 1). The collected specimens were immediately photographed; morphometric measurements were taken and preserved in $70 \%$ alcohol after anaesthetized. The specimens were identified as per the standard identification keys of Henderson (1893), Alcock (1910a,b), and Ng et al. (2008). The specimens were deposited in the Aquatic Animal Biodiversity Museum of the Department of Industrial Fish \& Fisheries, Asutosh College, Kolkata (Reg. No. AABM/IFF/ AC/CRUSTACEA/CRAB-1 to 2). Bengal, India. Journal of Threatened Taxa 13(13): 20084-20089. https://doi.org/10.11609/jott.7465.13.13.20084-20089

Copyright: (c) Das 2021. Creative Commons Attribution 4.0 International License. JoTT allows unrestricted use, reproduction, and distribution of this article in any medium by providing adequate credit to the author(s) and the source of publication.

Funding: West Bengal Biodiversity Board; Memo No. 1221/3K (Bio)-5/2019.

Competing interests: The author declares no competing interests.

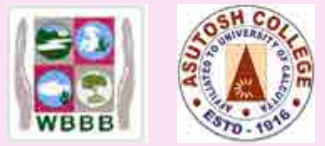

Acknowledgements: The author is grateful to Shri Bishu Tirkey, a resident of Cooch Behar district for his support in the field. Author thanks vice principal, Asutosh College for research facilities. The author is also grateful to West Bengal Biodiversity Board for financial support. The author gratefully acknowledges three anonymous reviewers and subject editor for their constructive comments and valuable suggestions. 


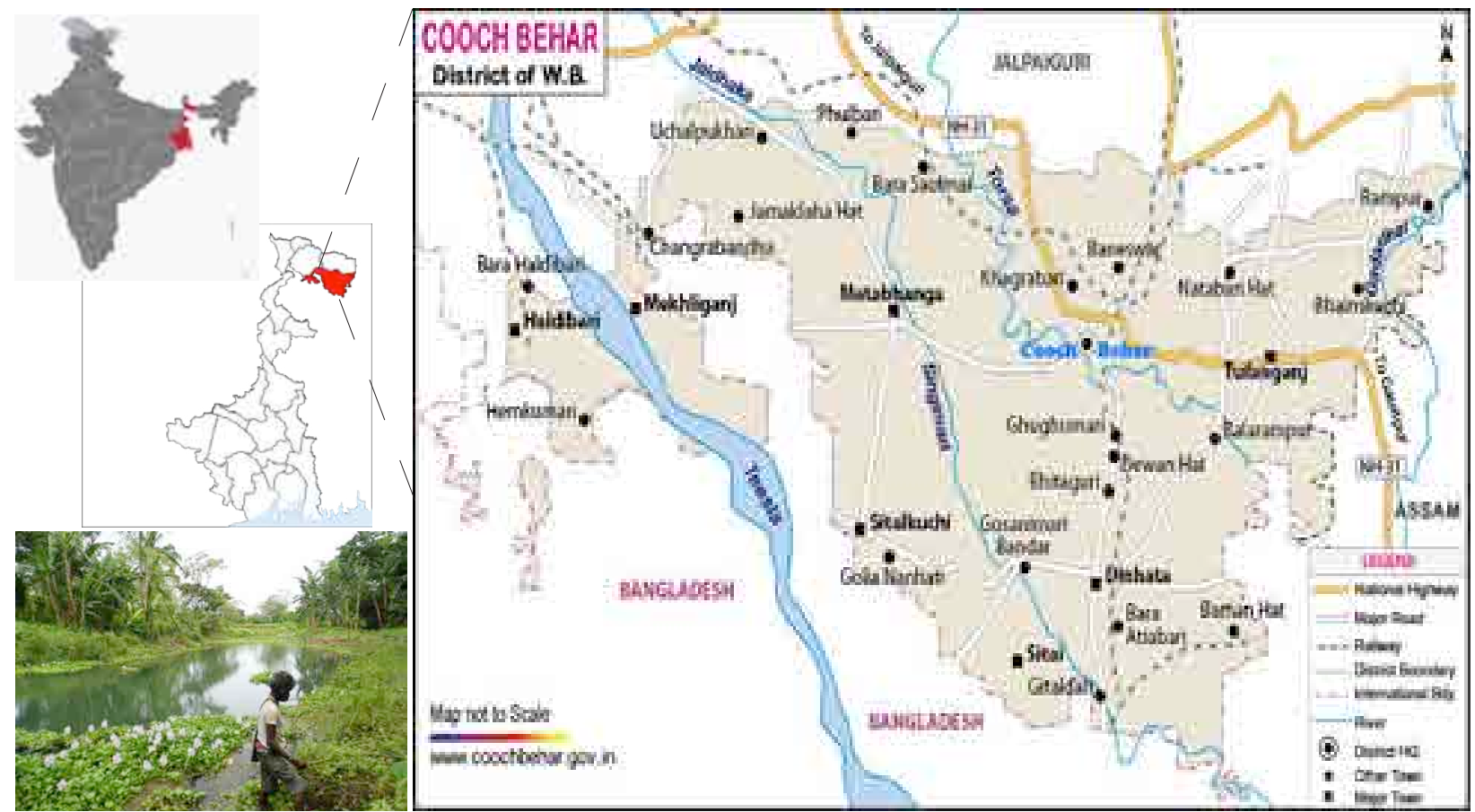

Image 1. Location of the study area $\left(26.229^{\circ} \mathrm{N}, 89.255^{\circ} \mathrm{E}\right.$, elevation $\left.32 \mathrm{~m}\right)$. Source: Official website of Cooch Behar district, Government of West Bengal <www.coochbehar.gov.in>

\section{TAXONOMY}

Class Malacostraca Latreille, 1802

Order Decapoda Latreille, 1802

Infraorder Brachyura Linnaeus, 1758

Section Eubrachyura Saint Laurent, 1980

Superfamily Gecarcinucoidea Rathbun, 1904

Family Gecarcinucidae, Rathbun, 1904

Genus Maydelliathelphusa Bott, 1969

\section{Maydelliathelphusa masoniana (Henderson 1893)} (Image 2A \& 3A)

Holotype: Telphusa masoniana Henderson, 1893 (pl. XXXVII. fig. 1-4)

Type locality: River Jumna, a series; North-West Provinces, four males (Day); "India" two dried specimens (Brit. Mus.)

Material examined: Reg. No. AABM/IFF/AC/ CRUSTACEA/CRAB/1 to 2, Date 16.v.2021, two individual (01 male and 01 female), small stream $\left(26.229^{\circ} \mathrm{N}\right.$, $89.255^{\circ} \mathrm{E}$ ) of the Brahmaputra River system in Cooch Behar district, West Bengal, India, collected by R.K. Das.

Measurement: Carapace length 55-60 mm, carapace width 75-82 mm, weight 180-190 g) (Details are presented in Table 1).

Diagnosis: The carapace is broader than long, slightly depressed; epigastric cristae distinct, rugose, located somewhat anterior to postorbital cristae without merging with the latter (Image 2A, 3A); postorbital cristae well defined towards the sides; a wide gap between frontal margin and postorbital cristae; external orbital tooth prominent; anterolateral margin with prominent epibranchial tooth; wide frontal margin, frontal median triangle incomplete (Image 2B \& 3B); cervical groove well developed; mesogastric furrow deep, slightly bifurcated posteriorly; chelipeds asymmetric and massive (Image $2 \mathrm{E})$, carpus with a strong spine, propodus and dactylus with strong teeth which can meet only at the tips creating a wide gap between them (Image $2 \mathrm{E}$ ); $6^{\text {th }}$ pleonal somite of adult male slightly longer than breadth with concave lateral margin (Image 2F).

Description: The morphometric measurements of the identified species are presented in Table 1 . The carapace enlarged, broader than length $(\mathrm{cw} / \mathrm{cl}=1.36)$, slightly depressed, dorsal surface smooth; epigastric cristae distinct, rugose, located anterior to postorbital cristae without merging with the latter; postorbital cristae well defined towards the sides, a wide gap between frontal margin and postorbital cristae (Image 2A, 3A); orbits large, external orbital tooth prominent; wide frontal margin ( $\mathrm{fw} / \mathrm{cw}=0.18)$; anterolateral margin with prominent epibranchial tooth; cervical groove well defined; mesogastric furrow deep, slightly bifurcated posteriorly; eyes smaller than orbital space, eyestalk short, narrow (Image 2B, 3B ); mandibular palp three-segmented; $1^{\text {st }}, 2^{\text {nd }}$ maxilliped with long flagellum on exopods; $3^{\text {rd }}$ maxilliped almost cover buccal cavity when closed (Image 2B, 3B); 
Table 1. Morphometric measurement of carapace and right cheliped of the identified crab ( $\mathrm{mm})$.

\begin{tabular}{|l|c|c|}
\hline Characters & $\begin{array}{c}\text { M. masoniana } \\
(\mathbf{n}=\mathbf{1} \text { (Male) }\end{array}$ & $\begin{array}{c}\text { M. masoniana } \\
(\mathbf{n = 1 )} \\
(\text { Female) }\end{array}$ \\
\hline Carapace length & 60 & 55 \\
\hline Carapace width & 82 & 75 \\
\hline Distance between epibranchial tooth & 62 & 60 \\
\hline Frontal width & 15 & 14 \\
\hline Posterior width of the carapace & 28 & 26 \\
\hline Merus length & 38 & 32 \\
\hline Merus width & 25 & 20 \\
\hline Carpus length & 30 & 25 \\
\hline Carpus width & 27 & 20 \\
\hline Propodus length & 80 & 57 \\
\hline Propodus width & 36 & 27 \\
\hline Dactylus length & 55 & 42 \\
\hline
\end{tabular}

ischium subrectangular, longer than broad, with a narrow medial groove; merus nearly pentagonal, broader than long; exopod slender, longer than ischium, reaching the base of merus, with a long flagellum (Image 2D ).

Chelipeds smooth, asymmetrical and massive, right cheliped larger than the left (Table 2, 3) carpus, with strong spine, propodus and dactylus with 12 to 13 strong teeth which can meet only at the tips creating a wide gap between them (Image 2E); ambulatory legs (P2-P5) stout, shorter than chelipeds; P3 longest and P5 shortest, dactylus longer than propodus with four rows of spines on the margins.

Pleon of the male smooth, glabrous, conical; pleonal somites 1, 2 almost rectangular, narrower than somite 3; pleonal somites $3-5$ trapezoidal; $6^{\text {th }}$ pleonal somite slightly longer than breadth with concave lateral margin; telson conical with equal length and breadth (Image 2C, 2 F); thoracic sternites smooth, glabrous; suture S4/ S5, S5/S6, S7/S8 discernible; sternopleonal cavity deep, long, reaching to imaginary line joining cheliped coxae; G1 stout, distal portion tapering gradually, slightly turned outward; G2 elongated; G1 longer than G2, approximately 1.7 times the length of $\mathrm{G} 2$ (Image $2 \mathrm{G}$ ).

In the female, pleonal somite 1 is the shortest; pleonal somites $2-5$ are progressively longer; $6^{\text {th }}$ pleonal somite is longest (Image 3C, 3D); telson triangular; vulvae on S6 (VD/SW= approximately 0.38), large, deep, touching the suture S5/S6 (Image $3 \mathrm{E}$ ).

Colour: Dark brown in fresh condition.

Habit \& Habitat: M. masoniana creates small burrows at the adjoining areas of soil and water of the stream for living and breeding purpose (Image 4A-C). Their preferred
Table 2. Morphometric measurement of chelipeds (right and left) of M. masoniana (Male) in $\mathrm{mm}$.

\begin{tabular}{|l|c|c|}
\hline Podomeres & Right cheliped & Left cheliped \\
\hline Merus length & 38 & 37 \\
\hline Merus width & 25 & 21 \\
\hline Carpus length & 30 & 27 \\
\hline Carpus width & 27 & 23 \\
\hline Propodus length & 80 & 62 \\
\hline Propodus width & 36 & 27 \\
\hline Dactylus length & 55 & 42 \\
\hline
\end{tabular}

Table 3. Morphometric measurement of chelipeds (right and left) of M. masoniana (Female) in $\mathrm{mm}$.

\begin{tabular}{|l|c|c|}
\hline Podomeres & Right cheliped & Left cheliped \\
\hline Merus length & 32 & 30 \\
\hline Merus width & 20 & 18 \\
\hline Carpus length & 25 & 23 \\
\hline Carpus width & 20 & 18 \\
\hline Propodus length & 57 & 52 \\
\hline Propodus width & 27 & 22 \\
\hline Dactylus length & 42 & 33 \\
\hline
\end{tabular}

habitat is the small or narrow canals or streams with slowmoving water. They are nocturnal in habit.

Distribution: India: Uttar Pradesh (Krishnamurthy 1995), Assam, Meghalaya, Jammu \& Kashmir (Kotwal \& Sharma 2020), West Bengal (present study).

Conservation status: As per the IUCN Red List of threatened species, the species belongs to the Least Concern (LC) category (Cumberlidge 2008).

\section{Discussions}

The freshwater crab, M. masonia was originally described as Telphusa masonina in the year 1893 by Henderson using type locality of river Jumna, NorthWest Provinces, India. Alcock (1910) transferred the species to the sub-genus Barythelphusa Alcock, 1909 of the Genus Parathelphusa Edwards, 1853 using a specimen from northern to central India. Bott (1970) created the subgenus Maydelliathelphusa and placed the species in that subgenus in a revisionary work. Specimen collected in the present study is in agreement with the original description of M. masoniana. In an earlier study, Krishnamurthy (1995), reported the species from Uttar Pradesh, India. Recently, the species has been reported from Jammu \& Kashmir (Kotwal \& Sharma 2020). 


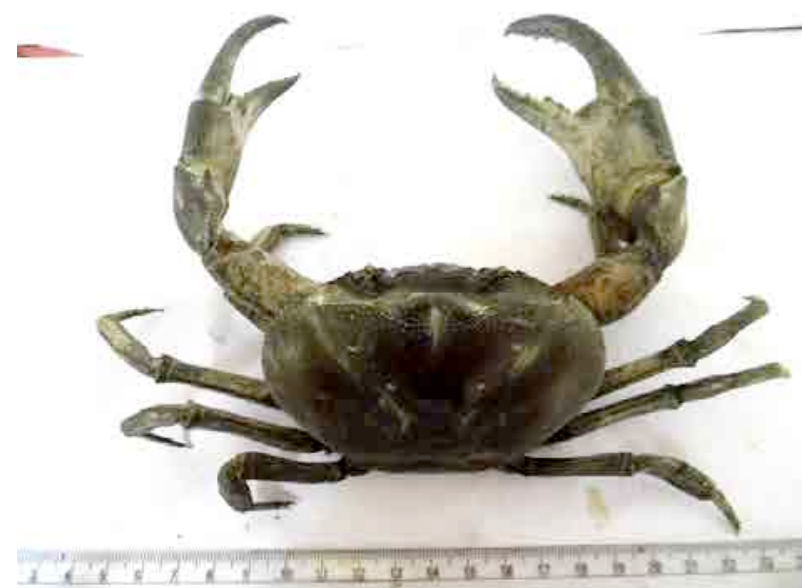

Image 2A. Maydelliathelphusa masoniana (Henderson, 1893) (Male) (Dorsal view). @ R.K. Das.

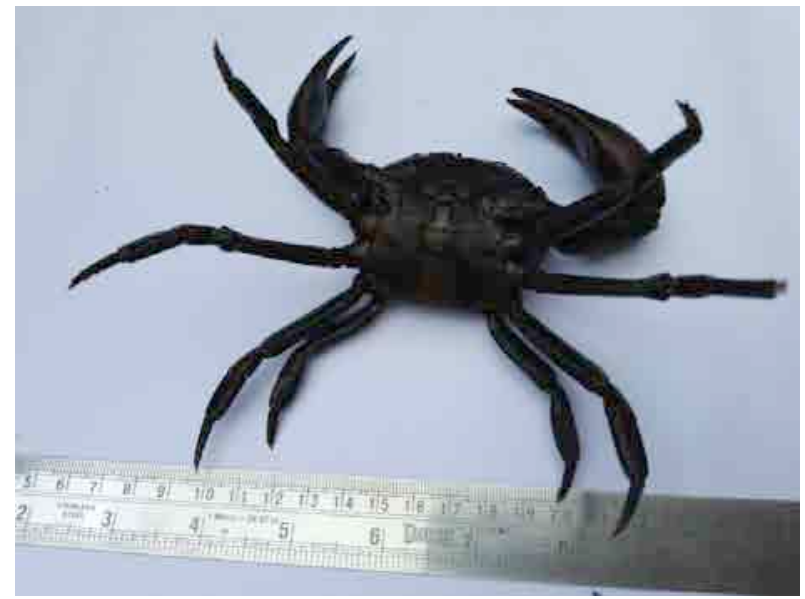

Image 2C. M. masoniana (Henderson, 1893) (Male) (Ventral view). (C) R.K. Das.

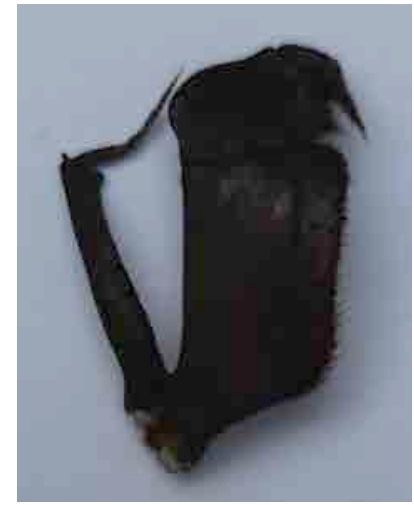

Image 2D. $3^{\text {rd }}$ maxilliped of a male M. masoniana. (C) R.K. Das.

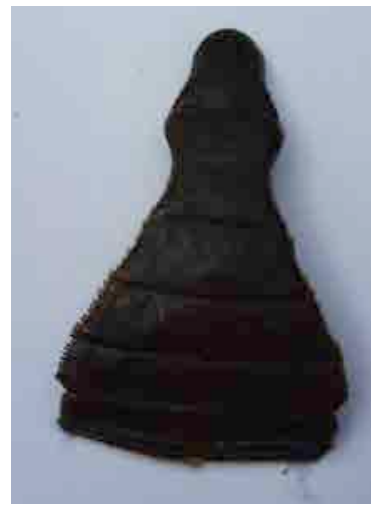

Image 2F. Pleon of a male $M$. masoniana. (C R.K. Das.

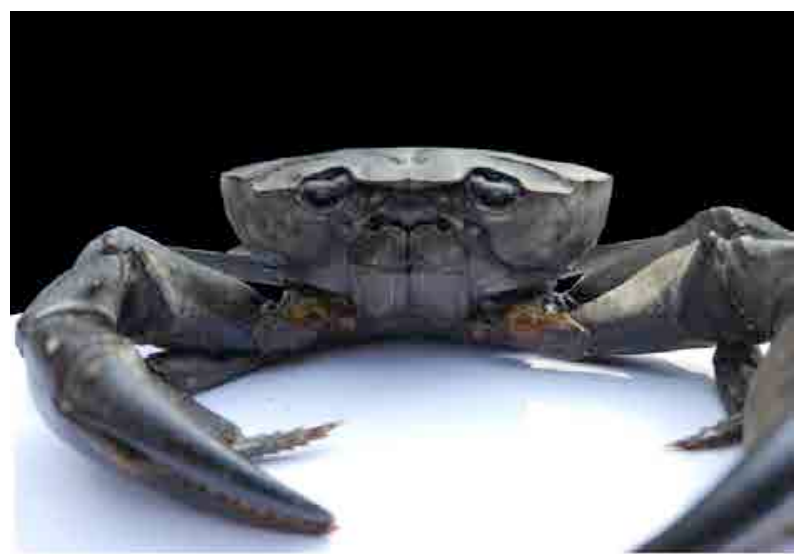

Image 2B. M. masoniana (Henderson, 1893) (Male) (Frontal view). (c) R.K. Das.

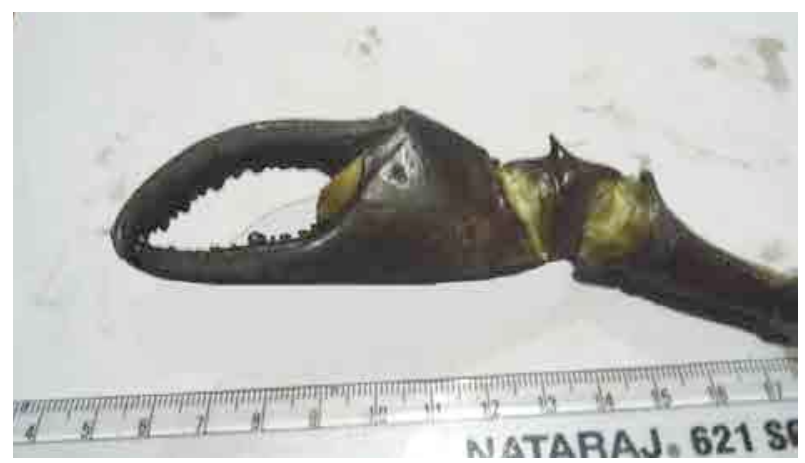

Image 2E. Right cheliped of a male M. masoniana. @ R.K. Das.

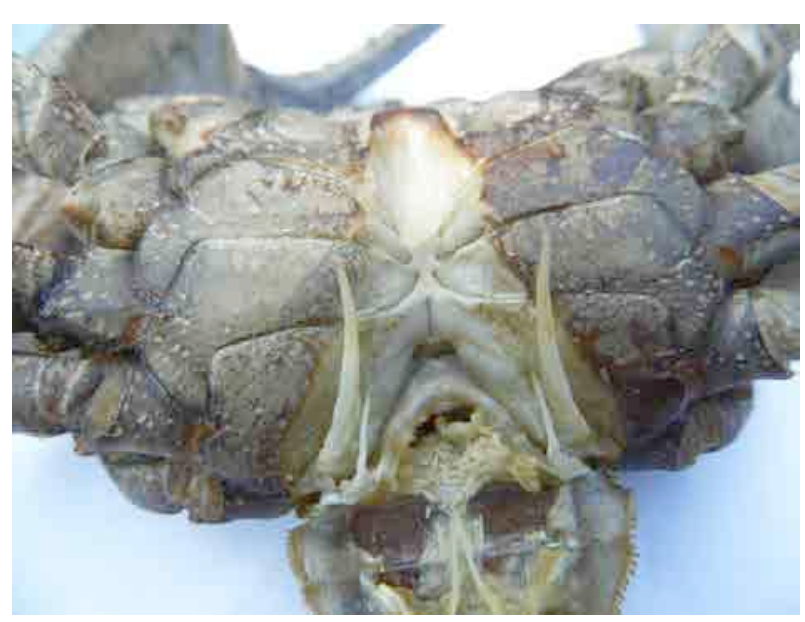

Image 2G. Sternopleonal cavity of a male crab showing G1 and G2. (C) R.K. Das. 


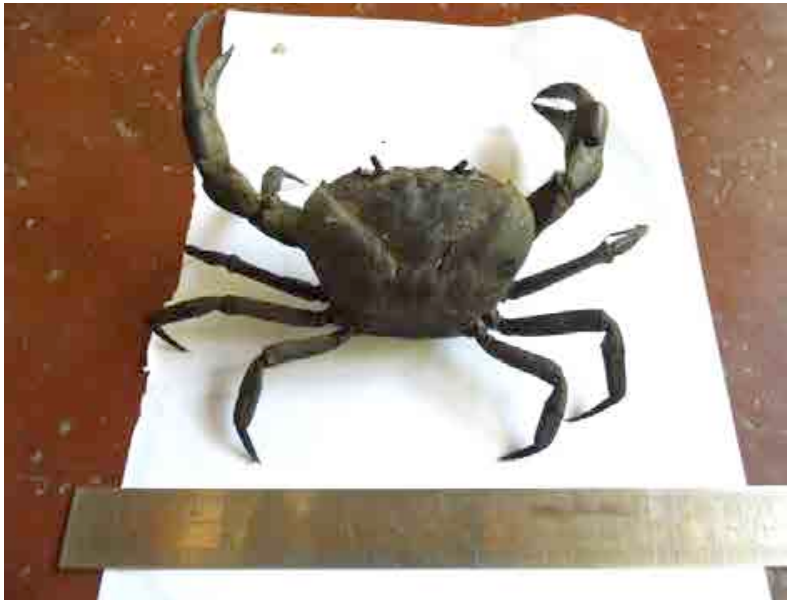

Image 3A. M. masoniana (Henderson, 1893) (Female) (Dorsal view). (C) R.K. Das.

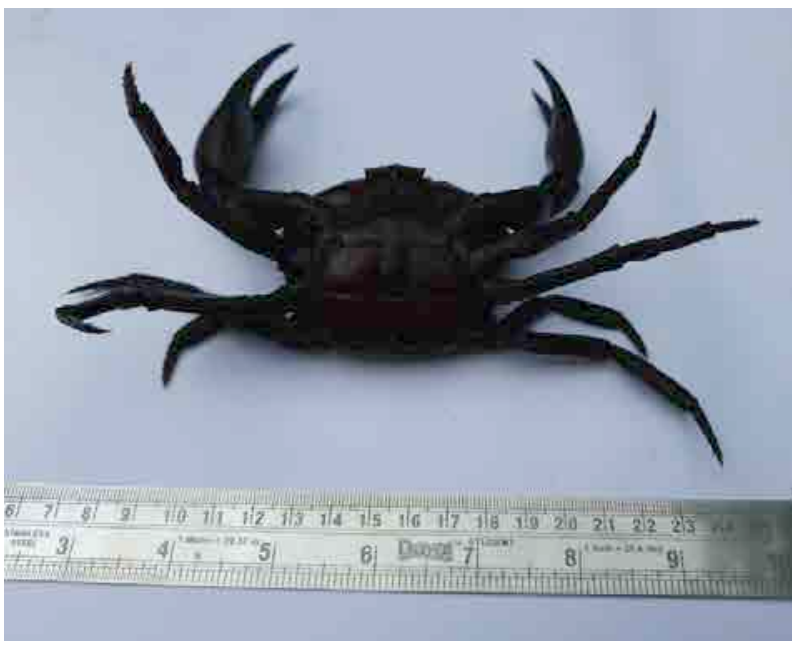

Image 3C. M. masoniana (Henderson, 1893) (Female) (Ventral view) (C) R.K. Das

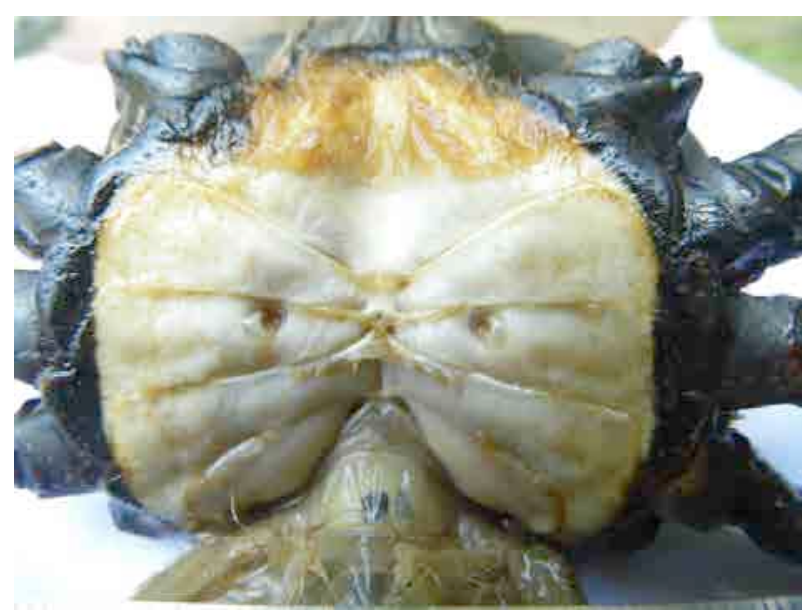

Image 3E. Thoracic sternite showing vulvae in female crab. ㄷ R.K. Das.

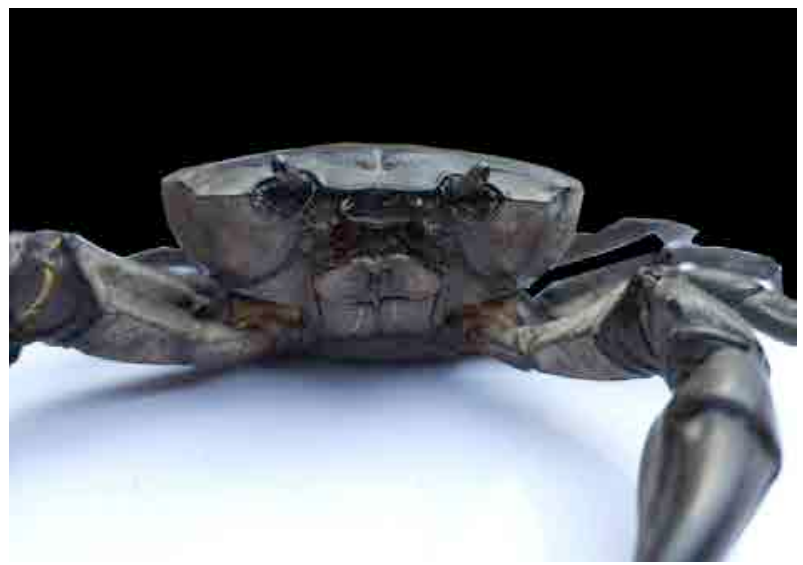

Image 3B. M. masoniana (Henderson, 1893) (Female) (Frontal view). (C) R.K. Das.

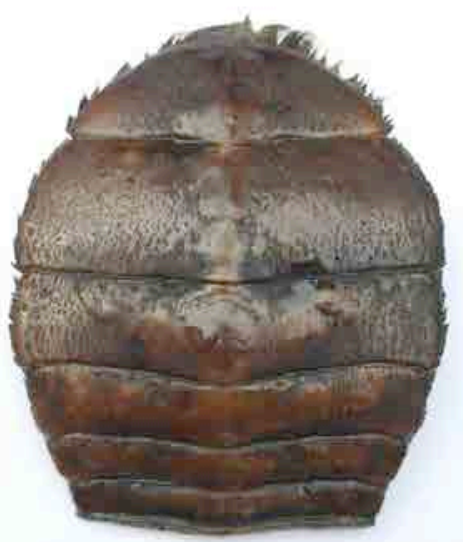

Image 3D. Pleon of a female M. masoniana () R.K. Das.

\section{CONCLUSION}

The present study extends the distribution of $M$. masoniana to West Bengal. As all the five species of the genus Maydelliathelphusa are similar morphologically, molecular taxonomy to confirm the morphological taxonomy of the species is warranted. Further studies are needed to investigate the biology, threat and conservation of this species, and to evaluate the potentiality of the species for commercial fisheries in that region.

\section{REFERENCES}

Alcock, A. (1910a). On the classification of the Potamonidae (Telphusidae). Records of the Indian Museum 5: 252-261.

Alcock, A. (1910b). Brachyura I, Fasc. II. The Indian fresh water crabsPotamonidae. Catalogue of the Indian Decapod Crustacea in the collection of the Indian Museum. Calcutta, 135 pp, pls. 1-14.

Bott, R. (1970). Die Süßwasserkrabben von Europa, Asien, Australien und ihre Stammesgeschichte. Eine Revision der Potamoidea und Parathelphusoidea (Crustacea, Decapoda). Abhandlungen der Senckenbergischen aturforschenden Gesellschaft 526: 1-338. 


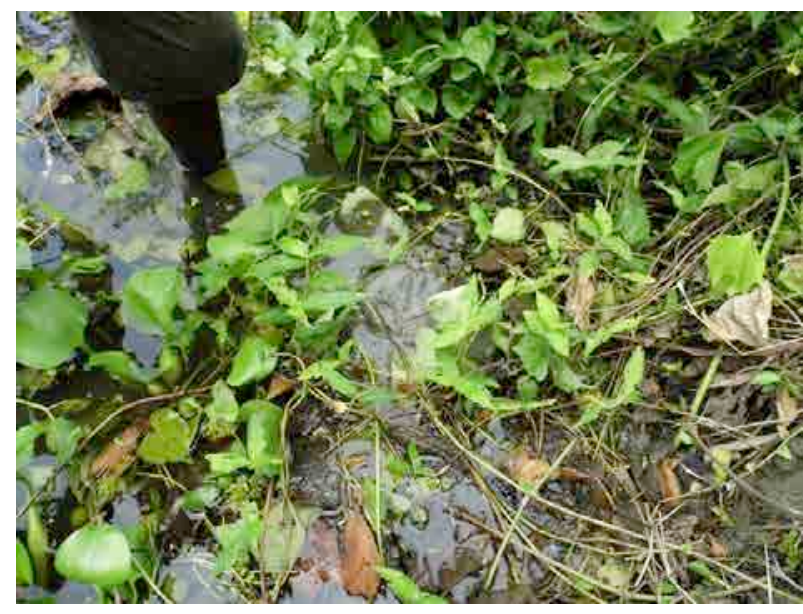

Image 4A. Crab burrow in the marginal area between soil and water. (C) R.K. Das.

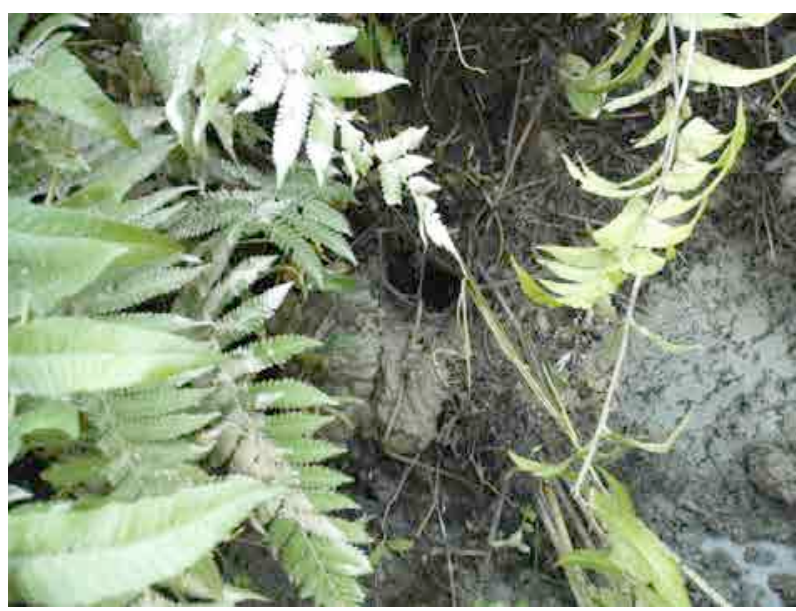

Image 4B. Crab burrow. (C R.K. Das.

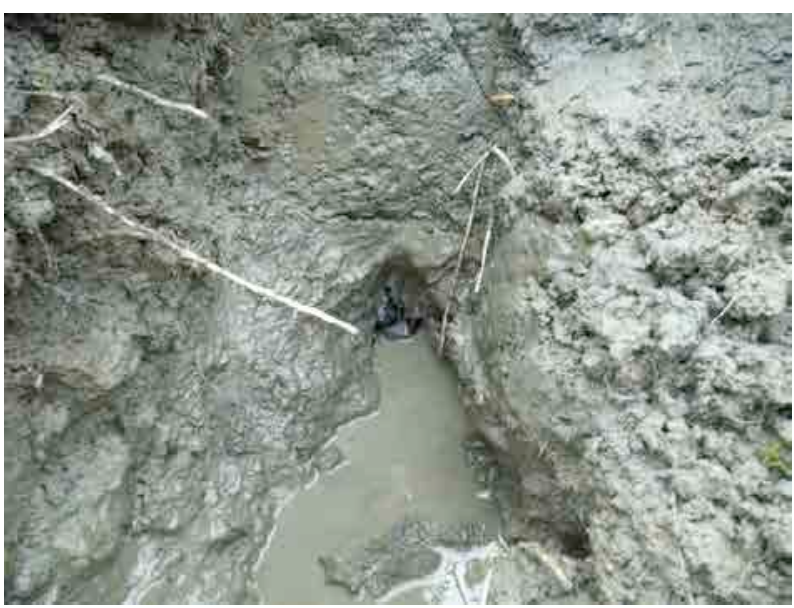

Image 4C. Location of a crab in a crab burrow. (C) R.K. Das.
Keys to the species of Maydelliathelphusa

1 (a) Epigastric and postorbital crests on either side united M. edentula

1 (b) Epigastric and postorbital crests are incompletely or indistinctly separated from one another .............................. 2

2 (a) External orbital tooth broad and blunt; lateral epibranchial tooth small and blunt, or obsolescent; carapace flattish

2 (b) External orbital tooth and lateral epibranchial tooth prominent; carapace convex/ tumid

4

3 (a) $6^{\text {th }}$ abdominal segment of male squarish with lateral side slightly concave M. Iugubris

3 (b) $6^{\text {th }}$ abdominal segment of male is longer than distal breadth..... . M. falcidigitis

4 (a) Carapace less convex; chelipeds are symmetric

M. harpax

4 (b) Carapace greatly convex; chelipeds are asymmetric M. masoniana

Cumberlidge, N. (2008). Maydelliathelphusa masoniana. The IUCN Red List of Threatened Species. e. T134371A3946162. Downloaded on 23 May 2021. https://doi.org/10.2305/IUCN.UK.2008.RLTS. T134371A3946162.en

Cumberlidge, N., P.K.L. Ng, D.C.J. Yeo, C. Magalhaes, M.R. Campos, F. Alvarez, T. Naruse, S.R. Daniels, L.J. Esser, F.Y.K. Attipoe, F-L. ClotildeBa, W. Darwall, A. Mclvor, J.E.M. Baillie, B. Collen \& M. Ram (2009). Freshwater crabs and the diversity crisis: Importance, threats, status, and conservation challenges. Biological Conservation 142: 16651673.

Deb, M. (1999). Crustacea: Decapoda: Crabs. In: State Fauna Series 3: Fauna of West Bengal, Zoological Survey of India 10: 345-403.

Harhoglu, M.M., A. Farhadi \& A.G. Harhoglu (2018). A review of the freshwater crabs of Turkey (Brachyura, Potamidae). Fisheries \& Aquatic Life 26: 151-158.

Henderson, J.R. (1893). A contribution to Indian carcinology. Transactions of the Linnean Society of London (Zoology), series 2(5): 325-458.

Kotwal, S. \& K.K. Sharma (2020). Studies on crab diversity in the freshwater habitats of Jammu, J\&K. International Journal of Life Sciences 8(2): 417-421.

Krishnamurthy, P. (1995). Crustacea: Decapoda. In: Himalayan ecosystem series: Fauna of Western Himalaya, Part I, Uttar Pradesh. Zoological Survey of India 1: 23

Ng, P.K.L., D. Guinot \& P.J.F. Davie (2008). Systema Brachyurorum: Part I. An annotated checklist of extant Brachyuran crabs of the world. The Raffles Bulletin of Zoology 17: 1-286.

Pati, S.K. (2021). Two new species of freshwater crabs of the genus Potamiscus Alcock, 1909 (Brachyura: Potamidae) from Nagaland, northeastern India. Nauplius - The Journal of the Brazilian Crustacean Society 29: e2021006. https://doi.org/10.1590/2358-2936e2021006

Valarmathi, K. (2018). Crustacea: Decapoda(Shrimps and crabs) In: Chandra, K., K.C. Gopi, D.V. Rao, K. Valarmathi \& J.R.B. Alfred. Current status of freshwater faunal diversity in India. Zoological Survey of India, Ministry of Environment, Forest and Climate Change, Government of India.

Yeo, D.C.J., P.K.L. Ng, N. Cumberlidge, C. Magalhaes, S.R. Daniels \& M.R. Campos (2008). Global diversity of crabs (Crustacea: Decapoda: Brachyura) in freshwater. Hydrobiologia 595: 275-286.

Wilin ZOGREACH 
Dr. John Noyes, Natural History Museum, London, UK

Dr. Albert G. Orr, Griffith University, Nathan, Australia

Dr. Sameer Padhye, Katholieke Universiteit Leuven, Belgium

Dr. Nancy van der Poorten, Toronto, Canada

Dr. Kareen Schnabel, NIWA, Wellington, New Zealand

Dr. R.M. Sharma, (Retd.) Scientist, Zoological Survey of India, Pune, India

Dr. Manju Siliwal, WILD, Coimbatore, Tamil Nadu, India

Dr. G.P. Sinha, Botanical Survey of India, Allahabad, India

Dr. K.A. Subramanian, Zoological Survey of India, New Alipore, Kolkata, India

Dr. P.M. Sureshan, Zoological Survey of India, Kozhikode, Kerala, India

Dr. R. Varatharajan, Manipur University, Imphal, Manipur, India

Dr. Eduard Vives, Museu de Ciències Naturals de Barcelona, Terrassa, Spain

Dr. James Young, Hong Kong Lepidopterists' Society, Hong Kong

Dr. R. Sundararaj, Institute of Wood Science \& Technology, Bengaluru, India

Dr. M. Nithyanandan, Environmental Department, La Ala Al Kuwait Real Estate. Co. K.S.C.,

Kuwait

Dr. Himender Bharti, Punjabi University, Punjab, India

Mr. Purnendu Roy, London, UK

Dr. Saito Motoki, The Butterfly Society of Japan, Tokyo, Japan

Dr. Sanjay Sondhi, TITLI TRUST, Kalpavriksh, Dehradun, India

Dr. Nguyen Thi Phuong Lien, Vietnam Academy of Science and Technology, Hanoi, Vietnam

Dr. Nitin Kulkarni, Tropical Research Institute, Jabalpur, India

Dr. Robin Wen Jiang Ngiam, National Parks Board, Singapore

Dr. Lional Monod, Natural History Museum of Geneva, Genève, Switzerland.

Dr. Asheesh Shivam, Nehru Gram Bharti University, Allahabad, India

Dr. Rosana Moreira da Rocha, Universidade Federal do Paraná, Curitiba, Brasi

Dr. Kurt R. Arnold, North Dakota State University, Saxony, Germany

Dr. James M. Carpenter, American Museum of Natural History, New York, USA

Dr. David M. Claborn, Missouri State University, Springfield, USA

Dr. Kareen Schnabel, Marine Biologist, Wellington, New Zealand

Dr. Amazonas Chagas Júnior, Universidade Federal de Mato Grosso, Cuiabá, Brasil

Mr. Monsoon Jyoti Gogoi, Assam University, Silchar, Assam, India

Dr. Heo Chong Chin, Universiti Teknologi MARA (UiTM), Selangor, Malaysia

Dr. R.J. Shiel, University of Adelaide, SA 5005, Australia

Dr. Siddharth Kulkarni, The George Washington University, Washington, USA

Dr. Priyadarsanan Dharma Rajan, ATREE, Bengaluru, India

Dr. Phil Alderslade, CSIRO Marine And Atmospheric Research, Hobart, Australia

Dr. John E.N. Veron, Coral Reef Research, Townsville, Australia

Dr. Daniel Whitmore, State Museum of Natural History Stuttgart, Rosenstein, Germany.

Dr. Yu-Feng Hsu, National Taiwan Normal University, Taipei City, Taiwan

Dr. Keith V. Wolfe, Antioch, California, USA

Dr. Siddharth Kulkarni, The Hormiga Lab, The George Washington University, Washington,

D.C., USA

Dr. Tomas Ditrich, Faculty of Education, University of South Bohemia in Ceske

Budejovice, Czech Republic

Dr. Mihaly Foldvari, Natural History Museum, University of Oslo, Norway

Dr. V.P. Uniyal, Wildlife Institute of India, Dehradun, Uttarakhand 248001, India

Dr. John T.D. Caleb, Zoological Survey of India, Kolkata, West Bengal, India

Dr. Priyadarsanan Dharma Rajan, Ashoka Trust for Research in Ecology and the Environment

(ATREE), Royal Enclave, Bangalore, Karnataka, India

\section{Fishes}

Dr. Neelesh Dahanukar, IISER, Pune, Maharashtra, India

Dr. Topiltzin Contreras MacBeath, Universidad Autónoma del estado de Morelos, México

Dr. Heok Hee Ng, National University of Singapore, Science Drive, Singapore

Dr. Rajeev Raghavan, St. Albert's College, Kochi, Kerala, India

Dr. Robert D. Sluka, Chiltern Gateway Project, A Rocha UK, Southall, Middlesex, UK

Dr. E. Vivekanandan, Central Marine Fisheries Research Institute, Chennai, India

Dr. Davor Zanella, University of Zagreb, Zagreb, Croatia

Dr. A. Biju Kumar, University of Kerala, Thiruvananthapuram, Kerala, India

Dr. Akhilesh K.V., ICAR-Central Marine Fisheries Research Institute, Mumbai Research

Centre, Mumbai, Maharashtra, India

Dr. J.A. Johnson, Wildlife Institute of India, Dehradun, Uttarakhand, India

Amphibians

Dr. Sushil K. Dutta, Indian Institute of Science, Bengaluru, Karnataka, India

Dr. Annemarie Ohler, Muséum national d'Histoire naturelle, Paris, France

\section{Reptiles}

Dr. Gernot Vogel, Heidelberg, Germany

Dr. Raju Vyas, Vadodara, Gujarat, India

Dr. Pritpal S. Soorae, Environment Agency, Abu Dubai, UAE.

Prof. Dr. Wayne J. Fuller, Near East University, Mersin, Turkey

Prof. Chandrashekher U. Rivonker, Goa University, Taleigao Plateau, Goa. India

Dr. S.R. Ganesh, Chennai Snake Park, Chennai, Tamil Nadu, India

Dr. Himansu Sekhar Das, Terrestrial \& Marine Biodiversity, Abu Dhabi, UAE
Birds

Dr. Hem Sagar Baral, Charles Sturt University, NSW Australia

Dr. Chris Bowden, Royal Society for the Protection of Birds, Sandy, UK

Dr. Priya Davidar, Pondicherry University, Kalapet, Puducherry, India

Dr. J.W. Duckworth, IUCN SSC, Bath, UK

Dr. Rajah Jayapal, SACON, Coimbatore, Tamil Nadu, India

Dr. Rajiv S. Kalsi, M.L.N. College, Yamuna Nagar, Haryana, India

Dr. V. Santharam, Rishi Valley Education Centre, Chittoor Dt., Andhra Pradesh, India

Dr. S. Balachandran, Bombay Natural History Society, Mumbai, India

Mr. J. Praveen, Bengaluru, India

Dr. C. Srinivasulu, Osmania University, Hyderabad, India

Dr. K.S. Gopi Sundar, International Crane Foundation, Baraboo, USA

Dr. Gombobaatar Sundev, Professor of Ornithology, Ulaanbaatar, Mongolia

Prof. Reuven Yosef, International Birding \& Research Centre, Eilat, Israel

Dr. Taej Mundkur, Wetlands International, Wageningen, The Netherlands

Dr. Carol Inskipp, Bishop Auckland Co., Durham, UK

Dr. Tim Inskipp, Bishop Auckland Co, Durham, UK

Dr. V. Gokula, National College, Tiruchirappalli, Tamil Nadu, India

Dr. Arkady Lelej, Russian Academy of Sciences, Vladivostok, Russia

Dr. Simon Dowell, Science Director, Chester Zoo, UK

Dr. Mário Gabriel Santiago dos Santos, Universidade de Trás-os-Montes e Alto Douro,

Quinta de Prados, Vila Real, Portugal

Dr. Grant Connette, Smithsonian Institution, Royal, VA, USA

Dr. M. Zafar-ul Islam, Prince Saud Al Faisal Wildlife Research Center, Taif, Saudi Arabia

Mammals

Dr. Giovanni Amori, CNR - Institute of Ecosystem Studies, Rome, Italy

Dr. Anwaruddin Chowdhury, Guwahati, India

Dr. David Mallon, Zoological Society of London, UK

Dr. Shomita Mukherjee, SACON, Coimbatore, Tamil Nadu, India

Dr. Angie Appel, Wild Cat Network, Germany

Dr. P.O. Nameer, Kerala Agricultural University, Thrissur, Kerala, India

Dr. Ian Redmond, UNEP Convention on Migratory Species, Lansdown, UK

Dr. Heidi S. Riddle, Riddle's Elephant and Wildlife Sanctuary, Arkansas, USA

Dr. Karin Schwartz, George Mason University, Fairfax, Virginia.

Dr. Lala A.K. Singh, Bhubaneswar, Orissa, India

Dr. Mewa Singh, Mysore University, Mysore, India

Dr. Paul Racey, University of Exeter, Devon, UK

Dr. Honnavalli N. Kumara, SACON, Anaikatty P.O., Coimbatore, Tamil Nadu, India

Dr. Nishith Dharaiya, HNG University, Patan, Gujarat, India

Dr. Spartaco Gippoliti, Socio Onorario Società Italiana per la Storia della Fauna "Giuseppe

Altobello", Rome, Italy

Dr. Justus Joshua, Green Future Foundation, Tiruchirapalli, Tamil Nadu, India

Dr. H. Raghuram, The American College, Madurai, Tamil Nadu, India

Dr. Paul Bates, Harison Institute, Kent, UK

Dr. Jim Sanderson, Small Wild Cat Conservation Foundation, Hartford, USA

Dr. Dan Challender, University of Kent, Canterbury, UK

Dr. David Mallon, Manchester Metropolitan University, Derbyshire, UK

Dr. Brian L. Cypher, California State University-Stanislaus, Bakersfield, CA

Dr. S.S. Talmale, Zoological Survey of India, Pune, Maharashtra, India

Prof. Karan Bahadur Shah, Budhanilakantha Municipality, Kathmandu, Nepal

Dr. Susan Cheyne, Borneo Nature Foundation International, Palangkaraja, Indonesia

Dr. Hemanta Kafley, Wildlife Sciences, Tarleton State University, Texas, USA

\section{Other Disciplines}

Dr. Aniruddha Belsare, Columbia MO 65203, USA (Veterinary)

Dr. Mandar S. Paingankar, University of Pune, Pune, Maharashtra, India (Molecular)

Dr. Jack Tordoff, Critical Ecosystem Partnership Fund, Arlington, USA (Communities)

Dr. Ulrike Streicher, University of Oregon, Eugene, USA (Veterinary)

Dr. Hari Balasubramanian, EcoAdvisors, Nova Scotia, Canada (Communities)

Dr. Rayanna Hellem Santos Bezerra, Universidade Federal de Sergipe, São Cristóvão, Brazil

Dr. Jamie R. Wood, Landcare Research, Canterbury, New Zealand

Dr. Wendy Collinson-Jonker, Endangered Wildlife Trust, Gauteng, South Africa

Dr. Rajeshkumar G. Jani, Anand Agricultural University, Anand, Gujarat, India

Dr. O.N. Tiwari, Senior Scientist, ICAR-Indian Agricultural Research Institute (IARI), New

Delhi, India

Dr. L.D. Singla, Guru Angad Dev Veterinary and Animal Sciences University, Ludhiana, India

Dr. Rupika S. Rajakaruna, University of Peradeniya, Peradeniya, Sri Lanka

Dr. Bahar Baviskar, Wild-CER, Nagpur, Maharashtra 440013, India

Reviewers 2018-2020

Due to pausity of space, the list of reviewers for $2018-2020$ is available online.

The opinions expressed by the authors do not reflect the views of the Journal of Threatened Taxa, Wildlife Information Liaison Development Society, Zoo Outreach Organization, or any of the partners. The journal, the publisher, the host, and the partners are not responsible for the accuracy of the political boundaries shown in the maps by the authors.

Journal of Threatened Taxa is indexed/abstracted in Bibliography of Systematic Mycology, Biological Abstracts, BIOSIS Previews, CAB Abstracts, EBSCO, Google Scholar, Index Copernicus, Index Fungorum, JournalSeek, National Academy of Agricultural Sciences, NewJour, OCLC WorldCat, SCOPUS, Stanford University Libraries, Virtual Library of Biology, Zoological Records.

NAAS rating (India) 5.64
Print copies of the Journal are available at cost. Write to:

The Managing Editor, JoTT,

c/o Wildlife Information Liaison Development Society,

No. 12, Thiruvannamalai Nagar, Saravanampatti - Kalapatti Road,

Saravanampatti, Coimbatore, Tamil Nadu 641035, India

ravi@threatenedtaxa.org 


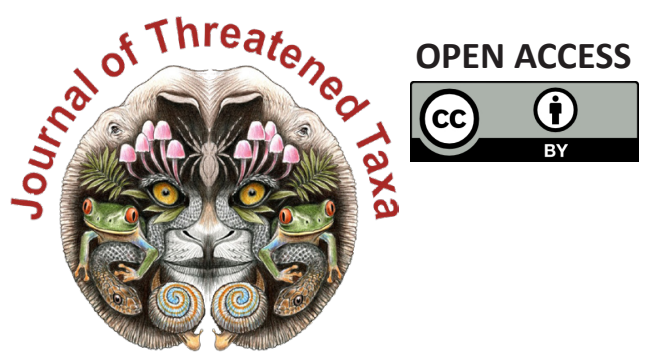

www.threatenedtaxa.org

The Journal of Threatened Taxa (JoTT) is dedicated to building evidence for conservation globally by publishing peer-reviewed articles online every month at a reasonably rapid rate at www.threatenedtaxa.org. All articles published in JoTT are registered under Creative Commons Attribution 4.0 International License unless otherwise mentioned. JoTT allows allows unrestricted use, reproduction, and distribution of articles in any medium by providing adequate credit to the author(s) and the source of publication.

ISSN 0974-7907 (Online) I ISSN $0974-7893$ (Print)

\section{November 2021 | Vol. 13 | No. 13 | Pages: 19887-20142 \\ Date of Publication: 26 November 2021 (Online \& Print) DOI: 10.11609/jott.2021.13.13.19887-20142}

\section{Article}

An inventory of geometrid moths (Lepidoptera: Geometroidea: Geometridae) of KalakadMundanthurai Tiger Reserve, India

- Geetha Iyer, Dieter Stüning \& Sanjay Sondhi, Pp. 19887-19920

\section{Communications}

Roadkills of Lowland Tapir Tapirus terrestris (Mammalia: Perissodactyla: Tapiridae) in one of its last refuges in the Atlantic Forest

- Aureo Banhos, Andressa Gatti, Marcelo Renan de Deus Santos, Leonardo Merçon,

Ilka Westermeyer, Natália Carneiro Ardente, Luis Francisco Oliveira Pereira Gonzaga, Lucas Mendes Barreto, Lucas Damásio, Tomas Lima Rocha, Vitor Roberto Schettino, Renata Valls, Helena Godoy Bergallo, Marcos Vinicius Freitas Silva, Athelson Stefanon Bittencourt, Danielle de Oliveira Moreira \& Ana Carolina Srbek-Araujo, Pp. 19921-19929

Scientific contributions and learning experiences of citizen volunteers with a small cat project in Sanjay Gandhi National Park, Mumbai, India

- Shomita Mukherjee, R. Nandini, P.V. Karunakaran \& Nayan Khanolkar, Pp. 19930-19936

Seasonal food preferences and group activity pattern of Blackbuck Antilope cervicapra (L., 1758) (Mammalia: Cetartiodactyla: Bovidae) in a semi-arid region of western Haryana, India

- Vikram Delu, Dharambir Singh, Sumit Dookia, Priya \& Kiran, Pp. 19937-19947

Studies on the habitats of Grey Francolin Francolinus pondicerianus (J.F. Gmelin, 1789) (Galliformes: Phasianidae) in northern districts of Tamil Nadu, India

- M. Pandian, Pp. 19948-19955

Recovery of vulture population in roosting and scavenging areas of Bastar and Bijapur, Chhattisgarh, India

- Sushil Kumar Dutta, Muntaz Khan, P.R.S. Nagi, Santosh Durgam \& Surabhi Dutta, Pp. 19956-19963

A geographical assessment of Chariganga and Arpara Beel (wetlands) of Nadia, West Bengal as a habitat of wetland birds

- Mehedi Hasan Mandal, Arindam Roy \& Giyasuddin Siddique, Pp. 19964-19975

Phenotypic plasticity in Barilius vagra (Hamilton, 1822) (Teleostei: Danionidae) from two geographically distinct river basins of Indian Himalaya

- Sumit Kumar, Sharali Sharma \& Deepak Singh, Pp. 19976-19984

Taxonomic notes, a new species, and a key to Indian species of the click beetle genus Cryptalaus Ôhira, 1967 (Coleoptera: Elateridae: Agrypninae)

- Harshad Parekar \& Amol Patwardhan, Pp. 19985-19999

Niche overlap of benthic macrofauna in a tropical estuary: diurnal variation

- Mário Herculano de Oliveira, Lidiane Gomes de Lima, Caroline Stefani da Silva Lima, Jéssica de Oliveira Lima Gomes, Franciely Ferreira Paiva, Graciele de Barros, Carlinda Railly Medeiros \& Joseline Molozzi, Pp. 20000-20010

Diversity of aquatic insects and biomonitoring of water quality in the upper Ganga River, a Ramsar site: a preliminary assessment

- Kritish De, Arkojyoti Sarkar, Kritika Singh, Virendra Prasad Uniyal, Jeyaraj Antony Johnson \& Syed Ainul Hussain, Pp. 20011-20018

Patterns of forest cover loss in the terrestrial Key Biodiversity Areas in the Philippines: critical habitat conservation priorities

- Bernard Peter O. Daipan, Pp. 20019-20032

The woody flora of Shettihalli Wildlife Sanctuary, central Western Ghats of Karnataka, India - A checklist

- Kanda Naveen Babu, Kurian Ayushi, Vincy K. Wilson, Narayanan Ayyappan \&

Narayanaswamy Parthasarathy, Pp. 20033-20055

Reproductive biology of Ophiorrhiza caudata C.E.C.Fisch. (Rubiaceae), an endemic and endangered creeping perennial herb of the Western Ghats, India

- Maria Theresa, Appukuttan Kamalabai Sreekala \& Jayalakshmi Mohanlal, Pp. 20056-20065
Short Communications

Successful rescue, medical management, rehabilitation, and translocation of a Red Panda Ailurus fulgens (Mammalia: Carnivora: Ailuridae) in Arunachal Pradesh, India - Jahan Ahmed, Sorang Tadap, Millo Tasser, Koj Rinya, Nekibuddin Ahmed \& Sunil Kyarong, Pp. 20066-20071

A rare photographic record of Eurasian Otter Lutra lutra with a note on its habitat from the Bhagirathi Basin, western Himalaya, India

- Ranjana Pal, Aashna Sharma, Vineet Kumar Dubey, Tapajit Bhattacharya, Jeyaraj Antony Johnson, Kuppusamy Sivakumar \& Sambandam Sathyakumar, Pp. 20072-20077

The first record of Medog Gliding Frog Rhacophorus translineatus Wu, 1977 (Anura: Rhacophoridae) from Chhukha District, Bhutan

- Sonam Lhendup \& Bal Krishna Koirala, Pp. 20078-20083

First record of a freshwater crab, Maydelliathelphusa masoniana (Henderson, 1893) (Decapoda: Brachyura: Gecarcinucidae) from West Bengal, India

- Ram Krishna Das, Pp. 20084-20089

Butterflies of Amrabad Tiger Reserve, Telangana, India

- Deepa Jaiswal, B. Bharath, M. Karuthapandi, Shrikant Jadhav, S. Prabakaran \& S. Rehanuma Sulthana, Pp. 20090-20097

An enumeration of the flowering plants of Kyongnosla Alpine Sanctuary in eastern Sikkim, India

- Sudhansu Sekhar Dash, Subhajit Lahiri \& Ashiho Asoshii Mao, Pp. 20098-20117

A new record of psychrotrophic Paecilomyces formosus (Eurotiales: Ascomycota) from India: morphological and molecular characterization

- Skarma Nonzom \& Geeta Sumbali, Pp. 20118-20123

Notes

Study on incidence and pathology of gastrointestinal parasitic infections in Nilgai Boselaphus tragocamelus in Hisar, Haryana, India

- Maneesh Sharma, B.L. Jangir, D. Lather, G.A. Chandratre, V. Nehra, K.K. Jakhar \& G. Narang, Pp. 20124-20127

An unusual vocalization of Brown Hawk-Owl Ninox scutulata (Raffles, 1822) (Aves:

Strigiformes: Strigidae) recorded from Kerala, India

- Riju P. Nair \& Shine Raj Tholkudiyil, Pp. 20128-20129

New distribution data on the genus Maripanthus Maddison, 2020 (Araneae: Salticidae) from southern India

- A. Asima, John T.D. Caleb, Dhruv A. Prajapati \& G. Prasad, Pp. 20130-20132

On the IUCN status of Boesenbergia albolutea and B. rubrolutea (Zingiberaceae) and typification of $B$. rubrolutea

- K. Aishwarya \& M. Sabu, Pp. 20133-20135

New records of mass seeding Cephalostachyum latifolium Munro (Poaceae) along the midelevation broadleaved forest of Sarpang district, Bhutan

- Jigme Tenzin, Sangay Nidup \& Dago Dorji, Pp. 20136-20139

Response

If habitat heterogeneity is effective for conservation of butterflies in urban landscapes of Delhi, India?' Unethical publication based on data manipulation

- Sanjay Keshari Das \& Rita Singh, Pp. 20140-20142

Publisher \& Host
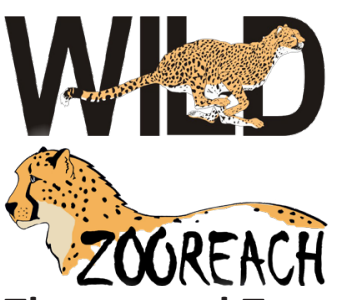

Threatened Taxa 